\title{
Oligo- és poliszacharidok, proteoglikánok
}

\author{
Jakab Lajos dr. \\ Semmelweis Egyetem, Általános Orvostudományi Kar, III. Belgyógyászati Klinika, Budapest
}

\begin{abstract}
Az írás a kis leucingazdag proteoglikánok összefoglalása után, amelyben utal a lurnican és a fibromodulin sajátosságaira, az inter- $\alpha$-tripszin-inhibitorral foglalkozik. Kiderült, hogy a molekula eredetileg is tartalmaz savanyú glikánláncot a neutrális oligoszacharidok mellett. A proteoglikán gazdag kapcsolatrendszerének összefoglalása után kiemeli ezen szerkezet „önfeláldozó” funkcionális viselkedését. Ismeretes „akutfázis-reaktáns” volta mellett érinti az ovárium múködését irányító szerepét, és említi antiinflammatorikus tulajdonságát. Ezt követően, a CD44-transzmembránszerkezet érintése után, összefoglalja sajátos hialuronánkapcsolatát, további élettani funkcióit és proteoglikán szerveződését. Ezután a hialuronán felépítésbeli sajátosságai, a fehérjementes láncstruktúrák kialakulása, a fragmentumok szerepe kerül tárgyalásra. A tanulmány összefoglalja az inter- $\alpha$-tripszin-inhibitorral összefüggő, szerteágazó kapcsolódási rendszerben elfoglalt szerepet is. Röviden érintődnek a hialuronán élettani, kórélettani vonatkozásai. Megfogalmazódik a kötőszöveti alapállomány felépítésében, múködésében, élettani és kóros viszonyok között betöltött nélkülözhetetlen szerep. Ezután érintődik a főbb, patológiás folyamatokat befolyásoló tevékenység, néhány klinikai vonatkozás. Röviden elmondható, hogy a hialuronsav egyedi fiziopatológiás szerepe az extracelluláris mátrix létrejöttében, múködésében rejlik. Összefoglalva elmondható, hogy az inflammatiós folyamatok során a nagy, egész molekula antiinflammatiós, a rövidebb láncok, fragmentumok sokasága proinflammatiós szignalizációs hatást gyakorol. Az inter- $\alpha$-tripszin-inhibitor struktúraszerveződést irányító molekula „beolvad” az egymással összefüggő, egymást feltételező processzusok sưrújébe - bár tulajdonképpen eltünik, hatásában azért tetten érhető. A TSG-6-ban és a C-reaktív fehérjében valódi, pozitív „akutfázis-reaktáns”-ra találhatunk.
\end{abstract}

Orv Hetil. 2018; 159(16): 620-627.

Kulcsszavak: kis leucingazdag proteoglikánok, inter- $\alpha$-tripszin-inhibitor, CD44, hialuronán, szerkezet/funkció

\section{Oligo- and polysacharides, proteoglycans}

After clearing up the confusion in the previously used nomenclature, the paper discusses the family of small-leucinrich glycoproteins. After mentioning the family and its role in the organisation of the ground substance and in the regulation of inflammation, one unique molecule of proteoglycans is presented. This molecule is the inter- $\alpha$-trypsin inhibitor. It has turned out that this peculiar molecule originally contains glycosaminoglycan beside the neutral carbohydrates. After summarizing the numerous connections of the proteoglycan molecule, the "self-sacrificing" nature of the molecule is presented. It is noted that the functions of the ovaries are also controlled by this molecule. The unique structure and fundamental function of the CD44 is also analysed. The CD44 is a transmembrane proteoglycan receptor with diverse functions and actions. The organisation has intramolecular, transmembrane sections, a stalk and one globular part and contains glycosaminoglycan and oligosacharids, too. The construction contains sialic acid residues at end positions of the molecular chains, which hinder it from joining other sialic acid structures in terminal positions. Therefore, this molecule has to be separated to open up a way for the sequencing neutral molecule (e.g., hyaluronan) to be attached. CD44 is the most important, but not the only receptor of hyaluronan. It can form connections with a lot of constructions, e.g., blood cells, the human endothelial, adventitial and mesenchymal. Human extracellular matrix proteinases can change the receptor's structures. Both the molecular and the supramolecular complexes boast unique features. The giant hyaluronan chains can connect to hyaluronan-binding proteoglycans - particularly hyaladherins to hyaluronectins - to create supramolecular connections and networks. The molecular mass of the fragments of hyaluronan is in the range of some $\mathrm{kDs}$, while the whole molecule weighs up to several million Ds. The fragments are independent masses and can form attachments by themselves. The fragments have important inflammatory effects. Previously unidentified proteoglycan fragments have also been identified. Five of the ten 
identified fragments are secreted after synthetizing and stored in the granula of human cells. These strange characteristics are connected to the features of chromogranins/secretogranins. Nevertheless, this is another system of the organism, the functional, molecular structures of which are synthetized in neuroendocrine cells.

Keywords: small-leucin-rich proteoglycans, inter- $\alpha$-trypsin inhibitors, CD44, hyaluronan, structure/functions

Jakab L. [Oligo- and polysacharides, proteoglycans]. Orv Hetil. 2018; 159(16): 620-627.

(Beérkezett: 2017. december 7.; elfogadva: 2018. január 23.)

\section{Rövidítések}

$\mathrm{ECM}=$ extracelluláris mátrix; GF = (growth factor) növekedési faktor; GG = glükózaminoglikán; GP = glükoprotein; HA = hialuronán; HABD = (HA-binding domain) HA-kötő domén; HA-BP-s = HA-kötő proteinek; infl. = inflammatio; I $\alpha \mathrm{TI}=$ inter- $\alpha$-tripszin-inhibitor; $\mathrm{PG}=$ proteoglikán; PRELP-PG $=$ prolin-arginin-leucin-gazdag PG; PS = poliszacharid; SLR-PG $=($ small-leucin-rich proteoglycan $)$ kis leucingazdag proteoglikán; TSG-6 = tumornekrózisfaktor-alfa $(\mathrm{TNF} \alpha)$-stimulált gén6 termék

Korábban a protein és a neutrális szénhidrát alkotta öszszetett vegyületeket a glikoprotein (GP) megnevezés illette. Igaz ugyan, hogy szigorúan véve már ez a megjelölés sem volt teljesen pontos, mert a fogalomkörbe a neuraminsavszármazékok is besorolódtak. Proteoglikán (PG) megjelölésen a fehérjék és a savanyú poliszacharidok (PS) alkotta szerkezeteket értettük. Kiderült azonban, hogy a neutrális és a savanyú szacharidok ugyanazon molekulán belül is előfordulnak elég gyakran. Így a proteoglikán megjelölés látszik a legkorrektebbnek. Igaz, hogy a GP-ek döntó részben a vérben és a testnedvekben lelhetők fel, bár a szövetekben is megtalálhatók, míg a savanyúglikán-szerkezetek döntően, de nem kizárólag, a szövetekben találhatók. Ismertté vált például, hogy az inter- $\alpha$-tripszin-inhibitor (I $\alpha \mathrm{TI})$ mindig tartalmaz glükózaminoglikán (GG)-láncot is neutrális szénhidrát mellett [1-3]. Korábban a neutrális PG-ok irodalma volt terjedelmesebb, ma már igen bóséges irodalma van a vegyes, összetett PG-oknak, GG-oknak is. Főként a szöveti előfordulású PG-ok irodalma gazdagodott, amelyek vérben, vizeletben és testnedvekben is fellelhetők, élettani és kóros folyamatokban egyaránt. A szérum-PG-ok és a szöveti PG-ok gazdag irodalmában az érintett vegyületek - például a gazdag szénhidráttartalmú orozomukoid vagy a makroglobulin, haptoglobin, transzferrin, coeruloplazmin stb. - sub titulo "fehérje" szerepelnek [4-6]. A szérum-PG-ok között ma már gyakrabban találkozunk például a külön famíliákba sorolt kis leucingazdag PG-okkal (SLR-PG), ezen a csoporton belül pedig a prolin-arginin-leucin gazdag PGokkal (PRELP-PG), bár szerkezetük kissé eltérő [2]. A savanyú szénhidrátokat tartalmazó molekulák a fehérjemaghoz tapadnak, és mindig tartalmaznak savanyú szénhidrátokat. $\mathrm{SO}_{4}$-gyökökkel rendelkezik a kondroitin-4 és -6- $\mathrm{SO}_{4}$, a dermatán- $\mathrm{SO}_{4}$, a keratán- $\mathrm{SO}_{4}$, a heparán- $\mathrm{SO}_{4} ; \mathrm{SO}_{4}$-mentes a hialuronán (HA) és a kondroitin. Az I $\alpha$ TI tartalmaz kondroitin-SO ${ }_{4}$-ot $[6,7]$. A szénhidrátot hordozó molekulák a proteinmaghoz (core) kapcsolódnak. A magok diverzitása jelentős, számuk 32 körül van. Meg kell jegyezni, hogy a savanyú PG-ok egyik része glükuronsavat, másik része iduronsavat tartalmaz. Az utóbbiak közé tartozik a biglikán, a dekorin, a verzikán, az a 5 1 l-integrin, a szerglicin és a CD44. Ennek pontos következménye még nem tisztázott, de feltûnő, hogy minden említett kompozíció szerepet kap az inflammatio (infl.), a naturális immunválasz lezajlásában.

\section{Az extracelluláris mátrix (ECM)}

AZ ECM felépítése változatos, inhomogén, szervenként, szövetenként eltérő. Tartalmaz sajátos sejtféleségeket (szövetspecifikus és egyéb), rostos elemeket (kollagén, elasztin, fibrilláris) és a befogadó, korábban amorfnak vélt úgynevezett alapállományt. A sejten kívüli komponensek együttese az ECM. Sokan a felsoroltak közül a két utóbbi összetevő-féleséget nevezik ECM-nak. A funkcionális elemek sokfélesége az ECM-ban tartózkodik hosszabb-rövidebb ideig. Vannak állandó elemek is. Az ECM az embrionális fejlődés motorja, a sejtdifferenciálódás bölcsője, a sejtek vándorlásának talaja. A molekuláris elemek mennyisége csak megbecsülhető. Ezek között az egyik legfontosabb a hialuronán (HA), amely minden szervben különböző mennyiségben található, szorosan együttmúk ödve a többi építő, mozgó elem sokaságával. További fontos molekuláris elemek a GP-ek, PG-ok, az enzimek, a cito- és kemokinek, a növekedési faktorok, a receptorszerkezetek és a mediátor és moderátor molekulák. A gazdag mozgó, építő, fibrilláris elemekből állnak össze a hálózatos struktúrák, membránszerkezetek. A kollagénrostok összetétele és mennyisége a molekulák egyedi tömege, a szövettípus és a funkcionális állapot függvényében széles skálán mozog. A HA például 100 és 1000 kD között, az elasztikus rostok $70 \mathrm{kD}$ körül mozognak. Főként a vese, a tüdő és a bőrszövet gazdag elasztinban. A molekuláris építőelemek között a HA emelhető ki. Az óriási, egyszálú szerkezet kiépítését hormonok, citokinek, növekedési faktorok (GF) vezérlik. A HA sok kapcsolódó molekulával kötődik össze. 
Első helyen kiemelhetők a HA-kötő proteinek (HABP-s), a TNF $\alpha$-stimulált gén-6 termék (TSG-6), és a PG-ok (béta-glikán, verzikán, neurokán, szindekán stb.). Az I $\alpha$ TI-família-tagok legfőbb funkciója az infl., sérülés lezajlásában betöltött szerep (akutfázis-reakció), továbbá az ováriumfunkció, és az oocytaevolúció, -funkció irányítása. A kollagén és az elasztin kóros fejlődése és felépítése klinikai következményekkel járhat (osteoporosis, osteoarthritis, aneurysma arteriarum, osteogenesis imperfecta stb.) [6-9].

\section{Kis leucingazdag PG (SLR-PG)-csoport}

Az SLR-PG-famíliába sorolódik a szérum prolin-arginin és a leucingazdag PG-ok is. A megismert tagok száma már meghaladja a tízet. Mind a szerkezet, mind a funkció egyedi sajátosságokkal ruházza fel az egyes tagokat. Több is (például biglikán, dekorin) tartalmaz kondroitin- $\mathrm{SO}_{4} \mathrm{~A}$-t és dermatán-SO $\mathrm{S}_{4}$-ot. Közöttük 50\%-os a szekvenciaazonosság.

A fibromodulinban tirozin- $\mathrm{SO}_{4}$ található, hasonlóan a neurokánhoz [6, 7]. Széles körü a komplementrendszer funkcióval való összefüggés. A fibromodulinkomplement aktiváló, mediátorok a fibromodulin, a prolargin és a biglikán. A gerjesztett hatás nem egyirányú, nem azonos; többségében gátló effektus érvényesül. Domináns a szénhidrátszerkezet-kötés. A komplementrendszer aktivációs útjai ismertek. Az elsődleges aktivációs út beindításában az immunglobulin G és $\mathrm{M}$ ( $\mathrm{IgG}, \operatorname{IgM})$, a C-reaktív protein, a lipopoliszacharid (LPS) és a DNS-rendszer jeleskedik. Az alternatív aktivációs utat az instabil C3-as komponens autoaktivációja indítja meg. A harmadik, úgynevezett lektinút esetében a mannózkötő lektinek és a szénhidrátban gazdag molekulák kötése a determináns. A Clq köt dekorint, továbbá fibronektint, laminint, fibromodulint. De csak az utolsó komponens, az SLR-PG aktivitásfokozó kapacitású. Az oszteoadherin faktor Hhoz kapcsolódva inhibitorként munkál, így válva fontos regulátorrá. Az említendő, vonatkozó klinikai folyamatok a lupus erythematosus disseminatus, a haemolyticus uraemiás szindróma és a glomerulonephritis. Kongenitális klinikai szindrómák hátterében is fellelhetők SLR-PGanomáliák, például Hutchinson-Gilford-szindróma (progeria), osteogenesis imperfecta, Ehlers-Danlosszindróma [6, 10-13]. Érdemes a lumikánt néhány szóval külön is megemlíteni: SLR-PG-tag, a csoportba sorolható többi taggal együtt egy-egy maghoz (core) csatolódnak a molekuláris elemek. A lumikán körülbelül 40 kD tömegű alakzat. A lumikán (önállósult magprotein) szinte minden szerv ECM-ában, sejtek felszínén fellelhető. Szulfatált tirozint tartalmaz, tehát egy szulfatált GP. A cornea keratokánt, keratán- $\mathrm{SO}_{4}$-ot tartalmaz, tehát neutrális $\mathrm{GP}+$ keratán-SO${ }_{4}$-tartalmú PG-molekula egyszerre. Mint a matrikinek általában, regulálja a sejtproliferációt és a sebgyógyulást (dekorin, biglikán stb.) $[14,15]$. A csoportidegen agrin, perlekán és szindekán más tulajdonságokkal rendelkezik. A csoporttagok szinte mindegyike osztozik a kollagénrost-szerkezeti hatás tekintetében. Az ECM-ban különböző mennyiségben, diffúzan helyezkednek el $[5,7]$.

A famíliatagok legfőbb funkciójaként a kötőszöveti mátrix struktúrájának megformálása, múködésének irányítása, épségben tartása, szükség esetén, például sérülés esetén vagy infl.-s folyamatokban a restitúció, szanáció regulációja említhető. A komplementrendszerrel való kapcsolat kiegészítendő azzal, hogy infl.-ban, annak lezajlásában a konnatális és adaptációs immunválasz mozgásba hozása és befolyásolása is kiemelt szerepei közé tartozik. Ki kell emelni a kollagénrostképzést is [16].

A cartilagoszövetben található többek között a kifejezetten negatív elektromos töltésû́ aggrekán nagy menynyiségben. Ugyanitt található a fibromodulin, a fibronektin, valamint a laminin. Ezek mind részesek a folyamatokban (például infl.). Az oszteoadherin a TGF $\beta$-t (transzformáló növekedési faktort) is bevonva köti az $\alpha$ V $\beta 3$-integrint. A TGF $\beta$ gátló hatása a szöveti fibrosis mértékének, az infl.-nak csökkenésével jár. Szöveti sérülés, károsodás után a restitúció csak összehangolt, együttes tevékenység eredménye lehet. Itt megemlítendő több klinikai vonatkozás, kóros folyamat. Ilyenek a polyarthritis chronica progressiva, az inflammatio chronica és a különböző osteoarthritises folyamatok. Különös figyelmet érdemel az atherosclerosis patogenezisében betöltött szerepkör [17-19] (1. táblázat).

1. táblázat |Az ismertebb kis leucingazdag proteoglikánok

\begin{tabular}{lccc}
\hline & $\begin{array}{c}\text { Extracelluláris } \\
\text { mátrix }\end{array}$ & Rostszövet & $\begin{array}{c}\text { Komplement- } \\
\text { rendszerrel } \\
\text { kapcsolat }\end{array}$ \\
\hline Asporin & + & + & - \\
Biglikán & & + & + \\
Kondroadherin $^{\circ}$ & + & + & + \\
Devorin $^{\circ}$ & + & - & + \\
Epifikán & + & + & - \\
Fibromodulin & + & + & + \\
Keratokán & + & + & - \\
Lumikán & + & + & + \\
Oszteoadherin & + & + & + \\
Osteoglicin & + & + & - \\
Opticin & + & + & + \\
Prolargin & + & + & + \\
\hline
\end{tabular}

Jelmagyarázat: ${ }^{\circ}$ kapcsolat a TGFß-val

\section{Inter- $\alpha$-tripszin-inhibitor (inter- $\alpha$-inhibitor)}

A humán szérumban fellelhető I $\alpha$ TI fehérje + szénhidrát molekula [20]. Szérumbeli koncentrációja 50 mg/dl körül mozog (tisztasági fok fontossága). Cerebralis liquor- 
ban, synovialis fluidumban, vizeletben egyaránt jelen van. A korábbi megnevezés változóban van: ma már egyre inkább inter- $\alpha$-inhibitorként említődik. Az utóbbi időben lényegesen bővültek az ismeretek a molekuláról, így az összetételbeli és a funkcionális jellegzetességek egyaránt jelentősen kiegészültek. Régebben GP-ként tartották számon, és ismert volt antiplazminkapacitása. $\mathrm{Az}$ összetétele a korábban fehérjének tartott bikunin (mag), a kis bikunin poliszacharidok (körülbelül $40 \mathrm{kD}$ ), a hozzá kötődő nehézlánc (körülbelül 75 kD), valamint az oligoszacharid-könnyúláncok. A maghoz rögzül a kondroitin- $\mathrm{SO}_{4}$-lánc, amelyhez a többi kapcsolódó molekula, a von Willebrand-molekula egy doménje és mások is kötődnek. Az oligoszacharidcsoportok fukóz- és sziálsavmolekulákat is tartalmaznak. Az úgynevezett nehézláncok fontos alkatrészek. Összesen négyféle nehézlánctípus ismeretes $(\mathrm{Hl}-4)$ [21-23]. Képződhetnek a tumornekrózisfaktor-stimulált gén-6 (TSG-6) hatására. Ezeknek két doménje van, amelyek közül az egyik az úgynevezett Link-modul, mely egyúttal szuperfamíliatagnak is tekintendő. A nehézláncok a molekulában szorosan egymás mellett helyezkednek el. A Link-modul és a nehézláncfragmentumok önálló funkcionális kapacitással rendelkeznek. A bikunintermelődést citokinek (IL6, IL1, TNF $\alpha$ ) szabályozzák, a TSG-6-ot hasonlóképpen ez magyarázza a korábban kapott besorolást. Az I $\alpha \mathrm{TI}$ „akutfázis-protein”. Aktív infl.-s folyamatokban a szérumban és a synovialis fluidumban a koncentráció emelkedik. A bikunin + TSG-6 + egy nehézlánc már kb. 120 $\mathrm{kD}$ tömeget jelent, az egymáshoz viszonyított molekularitás akvivalens. A bikunin és a mag együtt összetett szerkezet (fehérje-, fukóz- és sziálsavtartalmú oligoszacharidlánc és kondroitin- $\mathrm{SO}_{4}$ ). Májból, fibroblastokból származhatnak, de más sejtekből is eredhetnek. A TSG-6 legelőször a bikunin nehézlánchoz kötődik verso similiter. A leírásból is kiviláglik, hogy az I $\alpha$ TI nem stabil, állandó molekula. A sok kötődési lehetőség szinte állandóan változó molekuláris struktúrát eredményez. Funkcionális szerkezetű molekuláris struktúráról van szó [23-26]. Az I $\alpha$ TI-ben leginkább az 1-es és a 4-es nehézlánc tartható állandónak. Az I $\alpha$ TI embrionális organizátor, a késóbbiekben a multiplex kapcsolódási lehetőségei teszik az ECM egyik/a nélkülözhetetlen tagjává. A mátrixhoz tartozó molekuláris tömeg és celluláris alkatrész szövetenként változik. A cartilago szövetében a celluláris frakció körülbelül 10\%-ot tesz ki.

A vizsgálatok tanúsága szerint a TSG-6, az I $\alpha$ TI különösen nem tartható pusztán GP-nek. Ehhez az is hozzátehető, hogy a bikuninhez az oligoszacharidok mellett kapcsolódik egy kondroitin- $\mathrm{SO}_{4}$-lánc is. A kondroitin$\mathrm{SO}_{4}$-lánc 3-6 $\mathrm{SO}_{4}$-gyököt tartalmaz tetraszacharidonként. A monoszacharidláncok 27-34 szénhidrátmolekulát hordoznak [27]. Az I $\alpha$ TI antiplazmin-, valamint komplementrendszer-aktivációs hatása, infl.-t reguláló szerepe alapján fontos klinikai vonatkozásokkal találkozhatunk. Citrullinált I $\alpha$ TI-nehézlánc-ellenes autoantites- teket mutattak ki polyarthritis chronica progressivában, diagnosztikus és differenciális diagnosztikus felhasználhatóságot remélve [28]. Ismertté váltak I $\alpha$ TInehézláncokkal kapcsolatban végzett vizsgálatok pszichotikus betegek esetében a szérumban, valamint diabetes mellitusban (2-es típus). Ez utóbbi esetben nehézlánc typus-4 fragmentumait mutatták ki a vizeletben, vesekárosodás eseteiben [13,29-31].

\section{A CD44-receptor ( $R)$}

A CD44 egy nagy transzmembránfelszíni $\mathrm{R}$, amely az $\mathrm{N}$-terminálistól a C-terminálisig több részre tagolható. Mint lymphoid sejtmembrán R régóta ismert. Beszélhetünk rövid citoplazmatikus transzmembránszakaszról, rövid törzsről és a nagy HA-kötő doménről (HABD). A törzs és a globuláris szakasz tartalmaz szénhidrátokat, ezek tehát PG-molekulát alkotnak, valamint GP-eket. A törzsön kondroitin- $\mathrm{SO}_{4}$ és heparán- $\mathrm{SO}_{4}$ kötődik, így minősülnek PG-ná, míg a döntően globuláris rész birtokolta OS-csoportok és glikozilált szakaszok miatt beszélhetünk GP-ekről. A törzsön és a HABD-en N- és O-glikozilációs helyek egyaránt fellelhetők. A transzmembránszakaszhoz lipidmolekulák csatlakoznak poszttranszplantációs modifikáció révén [32-35]. A globuláris domén és az aglobuláris domén specifikus HA-kötőhelyek lévén adekvát struktúrák birtokosai. A HABD körülbelül 150 aminosavat inkorporál. Fontos megfigyelés, hogy az N- és O-glikán-kötő-helyek OS-csoportjai láncvégi pozícióban sziálsavat tartalmaznak. Ezek gátolják az OS felismerését és a kötődést. Ezeknek tehát le kell választódniuk a láncvégekről, így válik reálissá az OS-felismerés és -kötés. A láncvégi sziálsav tehát blokkolhatja a HA-kötést. A CD44 így hát nem szilárd, merev alakzat, alkalmazkodásra, funkcióváltásra képes [36-38]. A mátrixproteinek a CD44R finom szerkezetmódosítására képesek, például F-aktin közbejöttével. Az F-aktin-kötődés létrejöttében ezrin-radixin-moezin molekuláris szerkezet szerepe feltételezhető. E jelenség munkál a tumoros sejtek inváziójában. A radixinmolekula egyaránt képes kapcsolódni mátrixproteinázokkal és CD44-gyel. A mátrixban található egy metalloprotein, amely egy katalitikus és egy haemopexinszerú domént hordoz, és így szubsztrátumfelismerésre és degradációra egyaránt képes. Az ezrin-radixin-moezin komplexus egyik doménjének szerepe széles körben vizsgálat tárgya. A CD43, CD44, Pszelektin ligandum-1, neutrális endopeptidáz, ICAM2 szerepével kapcsolatban is folynak vizsgálódások [39, 40]. Így az említetteken túl a CD44 képes kapcsolódni radixinnal, sajátos következményekkel. A CD44R-funkció kiemelhető bizonyos patológiás folyamatokkal kapcsolatban. Ilyenek az infl.-s folyamatok, a cardiovascularis betegségek, valamint egyes tumoros betegségek (carcinomák) [38, 41, 42$]$. 


\section{Hialuronán. Tumornekrózisfaktor- stimulált gén-6 termék (TSG-6)}

A HA olyan hosszúláncokat képző glikánszerkezet, amely kivételként fehérje magot/komponenst nem tartalmaz. N-acetil-glükózaminból és glükuronsavból felépülő, oligoszacharidegységekből álló óriási poliszacharidmolekula. Molekuláris tömege széles skálán mozog, elérheti a milliós, akár többmilliós nagyságrendet. Hamar HABP-vel, hialuronektinnel társul. Ez egy óriási GP molekula a többi HA-kötő szerkezet között. Ezek közremúködésével, a SLR-PG-ok elengedhetetlen aktivitásával alakul ki az ECM-ban a szabályozott elrendeződés. A humán agyszövetben a kötődő HA-láncok nagy mennyiségben találhatók hialadherinnel együtt [43-46]. A HA más szerkezetekhez való kapcsolódásának különböző lehetőségei vannak. A hialadherinfamília-tagok a HA kötőhelyeihez csatolódnak Link-modul közbejöttével. Ez a TSG-6 100 aminosavból álló darabja. Más közvetítő molekulák is ismeretesek. Ilyenek az aggrekán, a brevikán, a neurokán és a verzikán).

A HA-láncok hossza nagyon változó. Ennek megfelelően a leghosszabb láncok molekuláris tömege elérheti a 7-11 kD-t. Embrióban a mesodermában nagy volumenben van jelen. Szerepe elengedhetetlen a mesenchyma, az ECM fejlódésében, kiépülésében, a finom szerkezet megformálásában, az érrendszer kialakulásában, épsége folyamatos megórzésében (adventitia, intima). A már érintett kapcsolódási képessége figyelemre méltó [47, 48].

A mennyiség, az elhelyezkedés, a strukturalitás szabályai elengedhetetlenek az ECM-funkció realizálódásában, a molekulákkal való folyamatos „szóváltás” révén. Ezekben hatásos közremúködő a TSG-6 egyik doménje, a Link-modul. Lehetôség nyílik a HA-kötő domén és a Link-modul találkozására. Ezt a folyamatot a nyirokerek endothelialis membránja, a macrophag sejtfelszín termékei előrelendítik. Lehetséges, hogy a HA-kötő domének együttesen tapadnak meg a Link-modulon. Ezen mechanizmusok módosíthatják egyes tumorsejtek mobilitását, szaporodását. A folyamatokban a lektikánok (aggrekán, brevikán, neurokán és verzikán) is közremúköodhetnek, különösen a verzikán gazdag GG-tartalmú molekulákban. A HA-depolimerizáció függ a környezeti pH-tól. A HABD-ek nem módosítják a depolimerizációt. A nagy tömegú HA szupramolekuláris hálózatot vagy membránszerú szerkezetet épít ki. A degradált vagy fragmentált HA kettôs arculatot hordoz. A hialuronidázok sok fajtája ismert. A peroxinitrit kizárólagosan az infl. szövetben degradálja a HA-t, de a heparint, heparán- $\mathrm{SO}_{4}$-ot nem. A HA összes mennyisége a humán szövetben körülbelül 20 gr. A korábban inertnek tartott alapanyagban a folyamatos turnover $1,5 \mathrm{~g} / \mathrm{nap}$. HA-ban igen gazdag a köldökzsinór, a cumulus oophoricus és az ízületi synovialis fluidum. A HA-TSG-6 keresztkötések felnőttkorban reverzibilisek, a láncok flexibilisek, a szükségletekhez alkalmazkodva. A Link-modul-família-tagok hasonlóan azok. Ezen tulajdonságoknak klinikai vonatkozásaik is vannak. Megtalálhatók a kondroprotekcióban, cirrhosis hepatisban, infarctus myocardii esetén, mindenfajta, de leginkább bőrsérülésben $[40,44,45]$.

A CD44, a nagy sejtmembránkomplexus a HA legfontosabb, specifikusnak mondható R-a. A polimer- és láncfragmentumok megkötésére egyaránt alkalmas. A CD44 különféle sejtek membránján lelhető fel, így lymphoid sejteken, macrophagokon, monocytákon, endothelium- és epitheliumsejteken, thrombocytákon, különösen infl. esetén. HA-stimulátorok a TNF $\alpha$, IL2, kemokinek. A monocytákat inkább az ILl, TNF $\alpha$, LPS stimulálja. Néhány citokin gátolja a HA-CD44 kötődést (például IL9, IL13). A specifikus antitestek hasonló hatásúak, és csökkentik az infl.-t. Az ECM-lebontási termékek, a fragmentumokat felismerô szerkezetek hasonlóan védelemre szolgálnak például infl., sérülés esetén, tehát a naturális és adaptációs immunválasz egyaránt aktiválódik. Az ECM-ban, az endotheliumon a HA + CD44 + I $\alpha$ TI együttesen hasonló védelmi szerepet játszanak. A HA-fragmentumok sokasága körülbelül $5 \mathrm{kD}$ molekuláris tömegtől kezdődően kerül felismerésre. A HA-fragmentum felszaporodása az egyik legkorábbi hírnök polyarthritis chronica progressivában experimentálisan. A komplexus nagyfokú adhezivitást mutat a leukocytákkal. A HA-komplexusok, amelyek TSG-6 mellett szükségszerúen tartalmaznak IaTI-alkatrészt is, nagymérvú felszaporodással járnak az infl.-s szövetekben, CD44-mediált fehérvérsejtgörgést (rolling) segítve [49, 50]. Hasonlóan segítik a TSG-6 molekula egyik doménjén keletkező tapadó felület kialakulását. Ez a Link-modul szuperfamília-tag, amely domináns funkcionális szereppel rendelkezik, mint már volt róla szó. A TSG-6 gyors oligomerizációt mutat, és így találkozik az oligomer HA-molekulákkal és -fragmentumokkal. Ezt gyors kötés követi I $\alpha$ TI-val. Hamar TSG-6 + HA keresztkötések képződnek. Az I $\alpha$ TI-nehézláncok leválva szabadon is találhatók a szövetekben, szérumban. A levált nehézláncok saját funkcióval bírnak, mint már említődött. A reakció vagy $\mathrm{Mg}++$ vagy $\mathrm{Mn++}$ ionok jelenlétében zajlik. A TSG-6-molekulák egymáshoz tapadva is lehetnek keresztkötések létrehozói [51, 52].

A TSG-6-nak tehát az I $\alpha$ TI-val összekapcsolódva széles körú összeköttetései keletkeznek. Az említetteken túl HA mellett kapcsolódhat GG-láncokkal (kondroitin$\mathrm{SO}_{4}$, dermatán- $\mathrm{SO}_{4}$, keratán- $\mathrm{SO}_{4}$, heparán- $\mathrm{SO}_{4}$, heparin), más PG-okkal (mint aggrekán, verzikán) vagy pentraxin-3-mal. Idesorolható még a tromboszpondin is. Igen fontos megemlíteni, hogy a TSG-6 egymagában is képes HA-keresztkötések kialakítására. Elősegíti a tromboszpondin-4- és a fibronektin-összeköttetést. A TSG-6 maga is PG-kompozíció. A Link-modul-lánc 95-100 aminosavból építkezik. Az I $\alpha$ TI + TSG-6 komplexus a különböző patológiás folyamatokban keletkező synovialis fluidumban éppúgy jelen van, mint arthritisek esetén [53-55]. Az I $\alpha$ TI organizátori kapacitását megosztva, különösen kóros viszonyok között, a PG TSG-6-tal szö- 
vődve behálózza az ECM-ot, a HA-val összefonódva bevonja a rostos szöveteket (kollagén, elasztin, fibrilláris) és a sejtes elemeket egyaránt. Az utóbbiak a kötőszöveti alapanyag tömegének körülbelül 10\%-át teszik ki [56, 57] (1. ábra).

\section{Következtetés}

A rövidségre törekvő, tárgyalásra került anyag feldolgozása rádöbbentett, hogy nehéz helyzetbe kerültünk. Az SLR-PG-ok összesítése azt kívánja, hogy a kérdések megválaszolását elölről kezdjük. Hamar kiderült ugyanis, hogy az I $\alpha$ TI nem illik az eddigi megismerések rendszerébe, ugyanis arról van szó, hogy az I $\alpha$ TI eredendően tartalmaz savanyú glikánt a neutrálisok mellett. Ez a létező, változó szerkezet ellenére bizton rögzíthető - a korábbi elképzelésekkel szemben. Nem adekvát tehát az eddigi megjelölés. A funkció ismerete sem elégséges az eddigi adatok tükrében: sokkal komplexebb, változékonyabb struktúrával, funkcionálisan sajátságosabb szerkezettel állunk szemben. Ezt a kevésbé ismeretes SLR-PG-ok is alátámasztják. A korábban is ismert „akutfázis-reaktáns" és antiplazmin mivolt, amelyek helytállóak, támogatták a szerkezet és a funkció elengedhetetlen újragondolását az SLR-PG-ok vonatkozásában. Az I $\alpha$ TI tehát olyan szerkezet, mely részben kettős arculatú, részben sokkal bonyolultabb, mobilisabb. Nem egyszerü GP-ról van tehát szó, mert a „GP-mag” mellett savanyú poliszacharidmolekula is megtalálható a molekulában.
De még így is leegyszerúsített a megfogalmazás, mert a bikunin- és a „kisbikunin”-mag is inkább PG. Nem egyszerü GP-ről van tehát szó, az eddigi megjelölés nem adekvát $[57,58]$. A szervezetben minden szövetben, testnedvben fellelhetők az SLR-PG-ok, valamint az I $\alpha$ TI [59].

Ezen molekulák fehérjéből és szénhidrátból állnak. Mindkét molekulaféle funkcionális tulajdonságokat hordoz, amelyek összeadódnak, kibővülnek. Ezen általános jellemvonás alól a HA kivétel, mert kizárólag poliszacharidkompozíció. Ezek a molekulák gyakorlatilag a humán szervezet minden szövetében fellelhetők. A HA tehát tiszta PS-alapmolekula, de első kapcsolódási partikuluma, a HA-kötőmolekula már PG [59-61]. Tiszta fehérjének minősíthető az albumin. Ha egy fehérjemolekula kizárólag neutrális glikáncsoportot hordoz, akkor beszélhetünk GP-ról. Egy kivétel azonban itt is található: a neutrális szénhidrátstruktúrák elég gyakran tartalmaznak sziálsavat, ami mannózamin és piroszőlősav kondenzációs terméke. Ilyen megengedés mellett beszél a nómenklatúra GP-ról. Ezek a szerkezetek tehát csak neutrális oligoszacharidokat tartalmaznak és gyakran az oligoszacharidlánc végén sziálsavakat. A lánc perifériás pozíciója fontos mind a szerkezet, mind a funkció szempontjából - ennek klinikai fontossága kézenfekvő. Ha a fehérjéhez kapcsolt oligoszacharidlánc(ok) és poliszacharidlánc(ok) terminális pozícióban hordozott sziálsava lehasad, az lehetővé teszi a felismerési és kapcsolatbeli képesség megváltozását. Változik a felismerés, lehetővé válik a moleku-

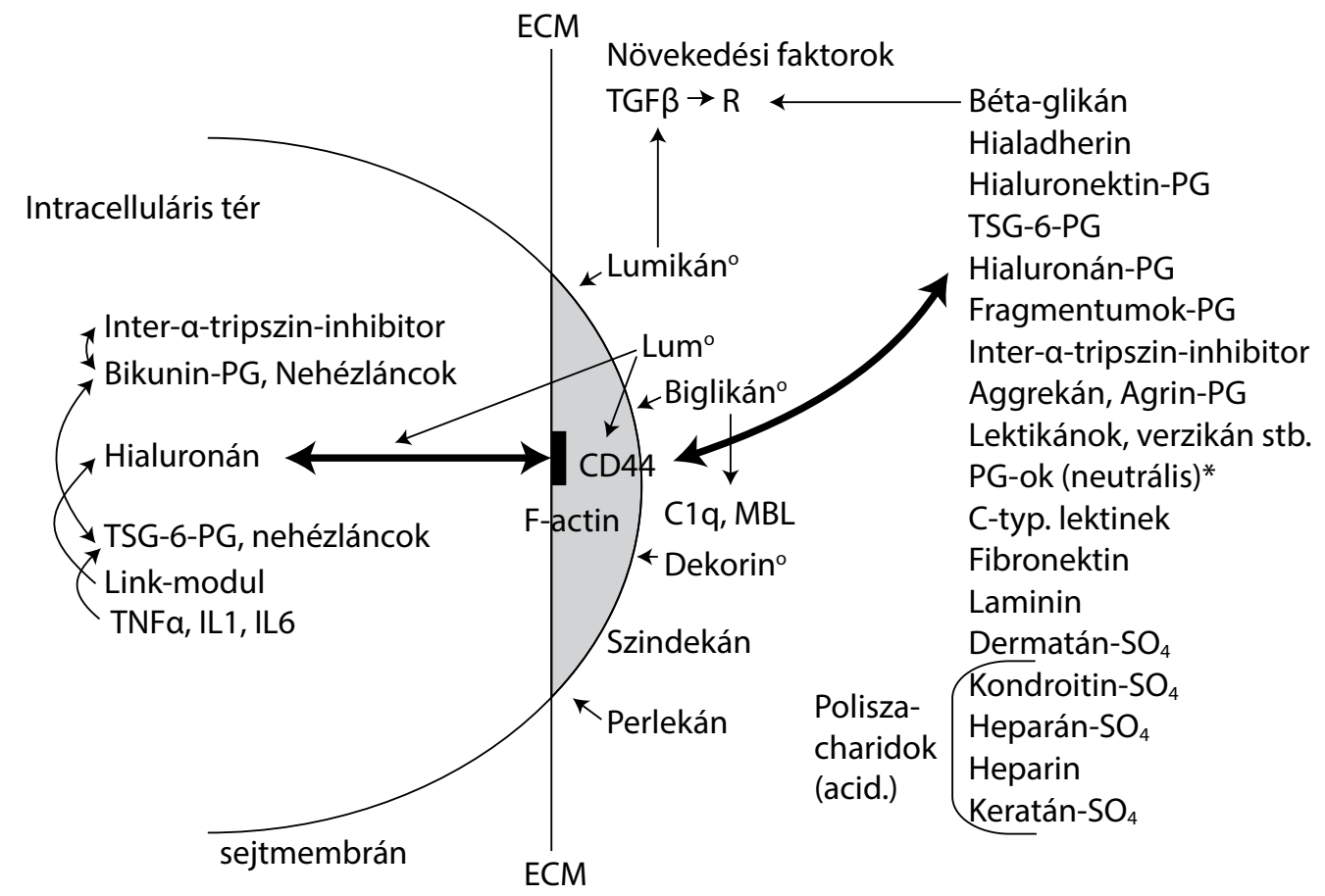

1. ábra

Extracelluláris mátrix. CD44-hialuronán-inter- $\alpha$-tripszin-inhibitor kapcsolódási rendszer

Jelmagyarázat: *sziálsavtartalom; ${ }^{\circ}$ matrikin hatás

$\mathrm{ECM}=$ extracelluláris mátrix; F-aktin = ezrin-radixin-moezin 
la-R kapcsolódás, vagy például a szérum asialo-GP és a májbeli asialo-GP-receptiorális kapcsolódás, elimináció. Ezen szerkezettípus nagyon gyakori a szervezeti „akutfázis-reakció” kompozíciói esetében. Infl. esetén széles határok között, de megváltoznak, pozitív vagy negatív irányba mozdulnak az úgynevezett „akutfázis-reakció” komponensei. Hepatocytamembrán károsodása egyúttal az asialo-GP-ek eliminációját hátráltatja [61, 62]. Ha a fehérje savanyú glikánokkal társul, savanyú PG-ról szólunk. Ezek amellett, hogy meghatározó strukturális elemei az ECM-nak, funkcionális kapacitást birtokolnak. Csodálatos tarkaságban találkozunk velük az organizmus minden szövetféleségében. Az ECM felépítésében kiemelkedő fontosságú a HA mennyisége, sokrétű funkcionális szerepe. Ez vonatkozik az embrionális fejlődésre, a szervezeti, szervi differenciálódásra az élettani feladatokban szövetenként változó módon, mennyiségben és minőségben. A savanyú PG-okról azt lehet és kell kiemelni, hogy a láncok különböző hosszúságú hexózamin + uronsav vagy iduronsav diszacharidok láncolata. A kondroitin kivételével $\mathrm{SO}_{4}$-gyököt mindannyian tartalmaznak, míg a keratán-SO $\mathrm{SO}_{4}$ uronsavval nem rendelkezik. A CD44 kapcsolódási rendje, funkciója páratlanul gazdag. Az I $\alpha$ TI szinte állandóan, folyamatosan alkatrész donorként épít és épül, szinte soha nem „kész” struktúrában.

Anyagi támogatás: A közlemény megírása anyagi támogatásban nem részesült.

A szerző a cikk végleges változatát elolvasta és jóváhagyta.

Érdekeltségek: A szerzőnek nincsenek érdekeltségei.

\section{Irodalom}

[1] Fries E, Kaczmarczyk A. Inter-alpha-inhibitor, hyaluronan and inflammation. Acta Biochim Pol. 2003; 50: 735-742.

[2] Garantziotis S, Hollingsworth JW, Ghanayem RB, et al. Inter- $\alpha$ trypsin inhibitor attenuates complement activation and complement-induced lung injury. J Immunol. 2007; 179: 4187-4192.

[3] Jakab L. The way of self-defence of the organism: inflammation. [A szervezeti önvédelem módja: a gyulladás.] Orv Hetil. 2013; 154: 1247-1255. [Hungarian]

[4] Ceciliani F, Pocacqua V. The acute phase protein $\alpha 1$-acid glycoprotein: a model for altered glycosylation during diseases. Curr Protein Pept Sci. 2007; 8: 91-108.

[5] Langford-Smith A, Day AJ, Bishop PN, et al. Complementing the sugar code: role of GAGs and sialic acid in complement regulation. Front Immunol. 2015; 6: 25

[6] Sjöberg P, Manderson GA, Mörgelin M, et al. Short leucine-rich glycoproteins of the extracellular matrix display diverse patterns of complement interaction and activation. Mol Immunol. 2009; 46: 830-839.

[7] Johnson JM, Young TL, Rada JA. Small leucine rich repeat proteoglycans (SLRPs) in the human sclera: identification of abundant levels of PRELP. Mol Vis. 2006; 12: 1057-1066.
[8] McEwan PA, Scott PG, Bishop PN, et al. Structural correlations in the family of small leucine-rich repeat proteins and proteoglycans. J Struct Biol. 2006, 155: 294-305.

[9] Matsushima N, Ohyanagi T, Tanaka T, et al. Super-motifs and evolution of tandem leucine-rich repeats within the small proteoglycans - biglycan, decorin, lumican, fibromodulin, PRELP, keratocan, osteoadherin, epiphycan, and osteoglycin. Proteins 2000; 38: 210-225.

[10] Groeneveld TW, Oroszlán M, Owens RT, et al. Interactions of the extracellular matrix proteoglycans decorin and biglycan with Clq and collectins. J Immunol. 2005; 175: 4715-4723.

[11] Poon IK, Hulett MD, Parish CR. Molecular mechanisms of late apoptotic/necrotic cell clearance. Cell Death Differ. 2010; 17: 381-397.

[12] Dube DH, Bertozzi CR. Glycans in cancer and inflammation potential for therapeutics and diagnostics. Nat Rev Drug Discov. 2005; 4: 477-488.

[13] Seidler DG. The galactosaminoglycan-containing decorin and its impact on diseases. Curr Opin Struct Biol. 2012; 22: 578-582.

[14] Yamanaka O, Yuan Y, Coulson-Thomas VJ, et al. Lumican binds ALK5 to promote epithelium wound healing. PLoS ONE 2013; 8: e82730.

[15] Jones AL, Hulett MD, Parish CR. Histidine-rich glycoprotein: A novel adaptor protein in plasma that modulates the immune, vascular and coagulation systems. Immunol Cell Biol. 2005; 83: 106-118.

[16] Kalamajski S, Oldberg A. The role of small leucine-rich proteoglycans in collagen fibrillogenesis. Matrix Biol. 2010; 29: 248253.

[17] Wells JM, Gaggar A, Blalock JE. MMP generated matrikines. Matrix Biol. 2015; 44-46: 122-129.

[18] López-Casillas F, Payne HM, Andres JL, et al. Betaglycan can act as a dual modulator of TGF- $\beta$ access to signaling receptors: mapping of ligand binding and GAG attachment sites. J Cell Biol. 1994; 124: 557-568.

[19] Rodriguez A, Friman T, Kowanetz M, et al. Phenotypical differences in connective tissue cells emerging from microvascular pericytes in response to overexpression of PDGF-B and TGF- $\beta 1$ in normal skin in vivo. Am J Pathol. 2013; 182: 2132-2146.

[20] Bost F, Diarra-Mehrpour M, Martin JP. Inter- $\alpha$-trypsin inhibitor proteoglycan family - a group of proteins binding and stabilizing the extracellular matrix. Eur J Biochem. 1998; 252: 339-346.

[21] Ly M, Leach FE, Laremore TN, et al. The proteoglycan bikunin has a defined sequence. Nat Chem Biol. 2011; 7: 827-833.

[22] Gomez-Toledo A, Nilsson J, Noborn F, et al. Positive mode LCMS/MS analysis of chondroitin sulfate modified glycopeptides derived from light and heavy chains of the human inter- $\alpha$-trypsin inhibitor complex. Mol Cell Proteomics 2015; 14: 3118-3131.

[23] Lamkin E, Cheng G, Calabro A, et al. Heavy chain transfer by tumor necrosis factor-stimulated gene 6 to the bikunin proteoglycan. J Biol Chem. 2015; 290: 5156-5166.

[24] Higman VA, Briggs DC, Mahoney DJ, et al. A refined model for the TSG-6 link module in complex with hyaluronan: use of defined oligosaccharides to probe structure and function. J Biol Chem. 2014; 289: 5619-5634.

[25] Jakab L. Connective tissue and inflammation. [Kötőszövet és inflammatio.] Orv Hetil. 2014; 155: 453-460. [Hungarian]

[26] Alessandri C, Conti F, Pendolino M, et al. New autoantigens in the antiphospholipid syndrome. Autoimmun Rev. 2011; 10: 609-616.

[27] Wisniewski HG, Colón E, Liublinska V, et al. TSG-6 activity as a novel biomarker of progression in knee osteoarthritis. Osteoarthritis Cartilage 2014; 22: 235-241.

[28] Liao CC, Chou PL, Cheng CW, et al. Comparative analysis of novel autoantibody isotypes against citrullinated-inter-alphatrypsin inhibitor heavy chain 3 (ITIH3) $)^{542-556}$ peptide in serum from Taiwanese females with rheumatoid arthritis, primary 
Sjögren's syndrome and secondary Sjögren's syndrome in rheumatoid arthritis. J Proteomics 2016; 141: 1-11.

[29] Fu G, Du Y, Chu L, et al. Discovery and verification of urinary peptides in type 2 diabetes mellitus with kidney injury. Exp Biol Med. 2016; 241: 1186-1194.

[30] Skliris A, Happonen KE, Terpos E, et al. Serglycin inhibits the classical and lectin pathways of complement via its glycosaminoglycan chains: Implications for multiple myeloma. Eur J Immunol. 2011 ; 41: 437-449.

[31] Brandl EJ, Lett TA, Chowdhury NI, et al. The role of the ITIH3 rs2535629 variant in antipsychotic response. Schizophr Res. 2016; 176: 131-135.

[32] Liu LK, Finzel, BC. Fragment-based identification of an inducible binding site on cell surface receptor CD44 for the design of protein-carbohydrate interaction inhibitors. J Med Chem. 2014; 57: 2714-2725.

[33] Patel S, Shaikh F, Devaraji V, et al. Insights into the structural perturbations of spliced variants of CD44: a modeling and simulation approach. J Biomol Struct Dyn. 2017; 35: 354-367.

[34] Yoo N, Lee HR, Son JM, et al. Genkwadaphnin promotes leukocyte migration by increasing CD44 expression via PKDl/NF- $\kappa \mathrm{B}$ signaling pathway. Immunol Lett. 2016; 173: 69-76.

[35] Artenjak A, Locatelli I, Brelih $\mathrm{H}$, et al. Immunoreactivity and avidity of IgG anti- $\beta 2$-glycoprotein I antibodies from patients with autoimmune diseases to different peptide clusters of $\beta 2$ glycoprotein I. Immunol Res. 2015; 61: 35-44.

[36] Richard Y, Huang C, Hudgens JW. Effects of desialylation on human al-acid glycoprotein-ligand interactions. Biochemistry 2013; 52: 7127-7136.

[37] Li L, Chaikof EL. Mechanical stress regulates syndecan-4 expression and redistribution in vascular smooth muscle cells. Arterioscler Thromb Vasc Biol. 2002; 22: 61-68.

[38] Varki A. Sialic acids in human health and disease. Trends Mol Med. 2008; 14: 351-360.

[39] Terawaki S, Kitano K, Aoyama M, et al. MTl-MMP recognition by ERM proteins and its implication in CD44 shedding. Genes Cells 2015; 20: 847-859.

[40] Thelin MA, Bartolini B, Axelsson J, et al. Biological functions of iduronic acid in chondroitin/dermatan sulfate. FEBS J. 2013; 280: 2431-2446.

[41] Shimizukawa M, Ebina M, Narumi K, et al. Intratracheal gene transfer of decorin reduces subpleural fibroproliferation induced by bleomycin. Am J Physiol Lung Cell Mol Physiol. 2003; 284: L526-L532.

[42] Varkoly G, Bencze J, Hortobágyi T, et al. The corneal wound healing and the extracellular matrix. [A cornealis sebgyógyulás és az extracelluláris mátrix.] Orv Hetil. 2016; 157: 995-999. [Hungarian]

[43] Petrey AC, de la Motte CA. Hyaluronan, a crucial regulator of inflammation. Front Immunol. 2014; 5: 101

[44] Rugg MS, Willis AC, Mukhopadhyay D, et al. Characterization of complexes formed between TSG- 6 and inter- $\alpha$-inhibitor that act as intermediates in the covalent transfer of heavy chains onto hyaluronan. J Biol Chem. 2005; 280: 25674-25686.

[45] Banerji S, Wright AJ, Noble M, et al. Structures of the CD44hyaluronan complex provide insight into a fundamental carbohydrate-protein interaction. Nat Struct Mol Biol. 2007; 14: 234239.

[46] Almond A. Visions and reflections (Minireview). Hyaluronan. Cell Mol Life Sci. 2007; 64: 1591-1596.

[47] Petrey AC, de la Motte, CA. Thrombin cleavage of inter- $\alpha$ inhibitor heavy chain 1 regulates leukocyte binding to an inflam- matory hyaluronan matrix. J Biol Chem. 2016; 291: 2432424334.

[48] Baranova NS, Inforzato A, Briggs DC, et al. Incorporation of pentraxin 3 into hyaluronan matrices is tightly regulated and promotes matrix cross-linking. J Biol Chem. 2014; 289: 3048130498.

[49] de la Motte CA, Hascall VC, Drazba J, et al. Mononuclear leukocytes bind to specific hyaluronan structures on colon mucosal smooth muscle cells treated with polyinosinic acid:polycytidylic acid: inter-alpha-trypsin inhibitor is crucial to structure and function. Am J Pathol. 2003; 163: 121-133.

[50] Guvench O. Revealing the mechanisms of protein disorder and $\mathrm{N}$-glycosylation in CD44-hyaluronan binding using molecular simulation. Front Immunol. 2015; 6: 305.

[51] Thaysen-Andersen M, Packer NH. Advances in LC-MS/MSbased glycoproteomics: getting closer to system-wide site-specific mapping of the $\mathrm{N}$ - and $\mathrm{O}$-glycoproteome. Biochim Biophys Acta 2014; 1844: 1437-1452.

[52] Hirooka T, Yoshida E, Eto K, et al. Methylmercury induces hyaluronan synthesis in cultured human brain microvascular endothelial cells and pericytes via different mechanisms. J Toxicol Sci. 2017; 42: 329-333.

[53] Park Y, Jowitt TA, Day AJ, et al. Nuclear magnetic resonance insight into the multiple glycosaminoglycan binding modes of the link module from human TSG-6. Biochemistry 2016; 55: 262-276.

[54] Baranova NS, Nilebäck E, Haller FM, et al. The inflammationassociated protein TSG-6 cross-links hyaluronan via hyaluronaninduced TSG-6 oligomers. J Biol Chem. 2011; 286: 2567525686.

[55] Lauer ME, Cheng G, Swaidani S, et al. Tumor necrosis factorstimulated gene-6 (TSG-6) amplifies hyaluronan synthesis by airway smooth muscle cells. J Biol Chem. 2013; 288: 423-431.

[56] Sanggaard KW, Hansen L, Scavenius C, et al. Evolutionary conservation of heavy chain protein transfer between glycosaminoglycans. Biochim Biophys Acta 2010; 1804: 1011-1019.

[57] Wick G, Grundtman C, Mayerl C, et al. The immunology of fibrosis. Annu Rev Immunol. 2013; 31: 107-135.

[58] Loh YP, Cheng Y, Mahata SK, et al. Chromogranin A and derived peptides in health and disease. J Mol Neurosci. 2012; 48: 347-356.

[59] Noborn F, Gomez Toledo A, Sihlbom C, et al. Identification of chondroitin sulfate linkage region glycopeptides reveals prohormones as a novel class of proteoglycans. Mol Cell Proteomics $2015 ; 14: 41-49$.

[60] Lévesque H, Girard N, Maingonnat C, et al. Localization and solubilization of hyaluronan and of the hyaluronan-binding protein hyaluronectin in human normal and arteriosclerotic arterial walls. Atherosclerosis 1994; 105: 51-62.

[61] Jakab L. Glycosaminoglycans, proteoglycans, atherosclerosis. [Glikozaminoglikánok, proteoglikánok, atherosclerosis.] Orv Hetil. 2004; 145: 795-803. [Hungarian]

[62] Jakab L. Physiological, pathophysiological and clinical significance of chromogranins/secretogranins. [A kromograninok, szekretograninok élettani, kórélettani, klinikai szerepéről.] Orv Hetil. 2017; 158: 1092-1099. [Hungarian]

(Jakab Lajos dr., Budapest, Kútvölgyi út 4., 1125 e-mail: nyulikinga@gmail.com) 